\title{
Uji Aktivitas Ekstrak Daun Pirdot (Sauraia vulcani Korth.) Terhadap Pertumbuhan Candida albicans Secara In Vitro
}

\author{
(Activity Test of Pirdot Leaf Extract (Sauraia vulcani Korth.) on Candida albicans Growth in Vitro)
}

\author{
Romauli Anna Teresia Marbun \\ Program Studi Farmasi, Fakultas Farmasi INKES MEDISTRA Lubuk Pakam, 20152 \\ Email korespondensi: romamarbun60@yahoo.com
}

(Article History: Received 5 October 2020; Revised 8 October 2020; Accepted 15 October 2020)

\begin{abstract}
ABSTRAK
Jamur Candida albicans merupakan jamur penyebab kandidiasis dan penyebab sariawan, lesi pada kulit, vulvavaginistis, candida pada urin (kandiduria), dan gastrointestinal kandidiasis. Salah satu jenis tanaman yang berkhasiat sebagai obat yaitu pirdot (Sauraia vulcani Korth.) dan bagian yang biasanya digunakan adalah bagian daun. Tujuan penelitian ini adalah untuk mengetahui aktivitas ekstrak daun pirdot terhadap pertumbuhan $C$. albicans secara in vitro. Penelitian ini merupakan penelitian true experiment dengan rancangan penelitian post-test only control group. Metode yang digunakan adalah difusi agar menggunakan teknik kirby bauer. Penelitian ini menggunakan 4 variasi konsentrasi ekstrak daun pirdot, yaitu 10\%, 20\%, 40\%, dan 80\%, kontrol positif (tablet ketokonazol), dan kontrol negatif (Dimethyl Sulfoxide). Data yang diperoleh dianalisa menggunakan statistika secara deskriptif. Hasil penelitian menunjukkan daya hambat mulai dari konsentrasi $10 \%$ sebesar $8,96 \mathrm{~mm}$ daya hambat tertinggi pada konsentrasi $80 \%$ sebesar $18,33 \mathrm{~mm}$. Kesimpulan ekstrak daun pirdot memiliki aktivitas antijamur terhadap C. albicans.
\end{abstract}

Kata kunci: Antijamur; Candida albicans; Metode Difusi; Saurauia vulcani Korth.

\begin{abstract}
Candida albicans is fungus that causes candidiasis and causes thrush, skin lesions, vulvavaginism, candidiuria and gastrointestinal candidiasis. One type of plant that has medicinal properties is pirdot (Sauraia vulcani Korth.) and the part that is usually used is the leaves. The purpose of this study was to determine the activity of pirdot leaf extract on the growth of C. albicans in vitro. This study was a true experiment with a post-test only control group research design. The method used agar diffusion using Kirby Bauer technique. This study used 4 variations concentration namely 10\%, 20\%, 40\%, and $80 \%$, positive control (ketoconazole tablets), and negative control (Dimethyl Sulfoxide). The data obtained were analyzed using descriptive statistical analysis. The results showed that the inhibitory from a concentration of $10 \%$ of $8.96 \mathrm{~mm}$, the highest inhibition was at $80 \%$ of $18.33 \mathrm{~mm}$. In conclusion, pirdot leaf extract has antifungal activity against $C$. albicans.
\end{abstract}

Keywords: Antifungal; Candida albicans; Diffusison Method; Saurauia vulcani Korth

\section{PENDAHULUAN}

Penyakit infeksi jamur menjadi perhatian khusus di berbagai negara dengan iklim tropis. Indonesia dengan iklim tropis disebabkan oleh udara yang lembab dan sanitasi yang masih kurang. Indonesia memiliki lingkungan yang padat penduduk dan tingkat sosial ekonomi yang rendah. Jamur Candida albicans dianggap sebagai spesies patogen dan salah satu penyebab infeksi tertinggi dibandingkan jamur yang lain. Jamur ini menjadi penyebab utama kandidiasis. Spesies C. albicans merupakan jamur opportunistik penyebab sariawan, lesi pada kulit, vulvavaginistis, candida pada urin (kandiduria), gastrointestinal kandidiasis yang dapat menyebabkan gastric ulcer, atau bahkan dapat menjadi komplikasi kanker (Kurniawan 2009, Sobel 2007, Nyirjesy 2001).

Pengobatan kandidiasis secara farmakologi dilakukan baik secara oral ataupun intravaginal menggunakan antibiotik golongan azol (Sherrard et al. 2011). Akan tetapi efek samping yang tidak diinginkan yang umum terjadi pada terapi dengan golongan azol adalah gangguan gastrointestinal dan dapat menyebabkan abnormalitas pada enzim hati (Katzung et al. 2014). Pengobatan ini dapat dipilih sebagai alternatif. Seiring perkembangan teknologi yang semakin canggih, pemakaian dan pendayagunaan obat tradisional di Indonesia 
mengalami peningkatan yang dramatis. Obatobatan tradisional kembali digunakan masyarakat yang mempercayai prinsip back to nature sebagai salah satu alternatif pengobatan, di samping obat-obatan sintetik yang berkembang di pasar (Fagbohun et al. 2012, Muhlisah 2005).

Obat tradisional yang berasal dari tumbuhan dan bahan-bahan alami murni memiliki efek samping, tingkat bahaya dan resiko yang jauh lebih rendah dibandingkan dengan obat kimia (Dalimartha 2006). Selain itu, penggunaan obat tradisional umumnya dipilih karena faktor biaya maupun ketidaknyamanan evaluasi medis. Obat tradisional yang umum digunakan untuk mengobati keputihan oleh masyarakat Indonesia diantaranya adalah daun sirih, beluntas dan jawer kotok (Sati et al. 2011).

Tanaman obat memiliki potensi untuk dijadikan fungisida alami. Hal ini dikarenakan tanaman obat mengandung senyawa metabolit sekunder yang dapat berperan sebagai antijamur. Metabolit sekunder seperti saponin, alkaloid, kumarin, xanton, flavanoid, asam lemak, senyawa fenol, terpen, minyak atsiri, lektin dan polipeptida telah dilaporkan memiliki aktivitas antijamur (Arif 2009, Lippold et al. 2009, Roking 2007).

Peneliti terdahulu terhadap daun tumbuhan pirdot ini, mengatakan bahwa tanaman ini telah dimanfaatkan oleh masyarakat Sumatera Utara sejak dulu untuk pengobatan luka dan mencegah terjadinya infeksi bakteri. Daun pirdot mengandung senyawa-senyawa berupa steroid, flavonoid, saponin, tannin, triterpen, dan juga memiliki daya antioksidan. Metabolit sekunder yang terdapat pada daun pirdot diduga berpotensi sebagai antijamur sehingga diperlukan pengujian untuk memutakhirkan potensi daun pirdot ini (Marbun et al. 2019, AlKobaisi et al. 2007, Mukherjee et al. 2003). Maka, peneliti melakukan pengujian antijamur ekstrak etanol pirdot terhadap C. albicans.

\section{METODE}

\section{Bahan}

Bahan-bahan yang digunakan adalah daun pirdot (Sauraia vulcani Korth.) yang diperoleh dari Parapat Kabupaten Simalungun, biakan Candida albicans yang diperoleh dari Laboratorium Mikrobiologi Rumah Sakit Grandmed Lubuk Pakam Sumatera Utara, medium Potato Dextrose Agar (Oxoid), etanol 96\% (Merck), tablet ketokonazole, Dimethyl Sulfoxide (DMSO) (Merck), akuades, alfa naftol
(Merck), amil alkohol (Merck), asam asetat anhidridat (Merck), asam klorida pekat (Merck), asam nitrat pekat (Merck), asam sulfat pekat (Merck), besi (III) klorida (Merck), bismuth nitrat, kalium iodida (Merck), kloroform (Merck), natrium hidroksida (Merck), kloralhidrat (Merck), serbuk magnesium (Merck), iodium, raksa (II) klorida (Merck), timbal (II) asetat (Merck) dan toluen (Merck).

\section{Penyiapan ekstrak tanaman}

Pengumpulan sampel dilakukan secara purposif, yaitu tanpa membandingkan dengan sampel yang sama dari daerah lain yang diperoleh dari Parapat Kabupaten Simalungun. Bagian tumbuhan yang diambil adalah bagian daun yang tua. Daun dibersihkan dari kotoran yang menempel lalu dikeringkan yang selanjutnya dibuat untuk pembuatan ekstrak daun pirdot.

Pembuatan ekstrak daun pirdot (EDP) dengan metode maserasi dengan pelarut etanol $96 \%$. Sebanyak 500 gram serbuk simplisia daun pirdot dimasukkan ke dalam bejana tertutup lalu ditambahkan etanol 96\% sebanyak 5 liter dan dibiarkan selama 5 hari terlindung dari cahaya sambil sering diaduk. Selanjutnya disaring, hasil saringan atau filtrat cair ekstrak etanol daun pirdot diuapkan menggunakan rotary evaporator (Heidolph, Jerman), kemudian diuapkan kembali menggunakan waterbath (Memmert, Jerman) untuk memastikan pelarutnya sudah menguap semua untuk mendapatkan ekstrak kental daun pirdot.

\section{Karakterisasi ekstrak}

Pemeriksaan kandungan metabolit sekunder dengan skrining fitokimia terhadap serbuk simplisia dan EDP, meliputi pemeriksaan glikosida, flavonoid, saponin, tanin dan steroid (Harborne 1998, Farnsworth 1966).

\section{Skrining Fitokimia}

Pemeriksaan alkaloid dilakukan dengan pereaksi Mayer, Bouchardat, dan Dragendorff. Pemeriksaan flavonoid dilakukan dengan menggunakan $0,1 \mathrm{~g}$ serbuk magnesium dan $1 \mathrm{ml}$ asam klorida pekat dan $2 \mathrm{ml}$ amil alkohol. Pemeriksaan glikosida dilakukan dengan menggunakan pereaksi Molish. Pemeriksaan saponin menggunakan pelarut asam klorida. Pemeriksaan tanin menggunakan pereaksi $\mathrm{FeCl}_{3}$. Pemeriksaan steroid menggunakan pereaksi asam sulfat. (Harborne 1998, Farnsworth 1966). 


\section{Penyiapan inokulum}

Koloni jamur diambil dari stok kultur dengan jarum ose steril lalu disuspensikan dalam tabung reaksi yang berisi $5 \mathrm{ml}$ larutan $\mathrm{NaCl}$ 0,9\% (Ditjen POM 1995). Kemudian diukur kekeruhan larutan pada panjang gelombang 520 nm sampai diperoleh transmitan 25\% (Turnip 2014).

\section{Pembuatan larutan uji ekstrak dengan berbagai konsentrasi}

Pembuatan larutan sampel ekstrak ekstrak daun pirdot dibuat dalam 4 konsentrasi yaitu $10 \%, 20 \%$, 40\%, dan $80 \%$ (g/ml). Konsentrasi uji dibuat dengan cara menimbang ekstrak masing-masing $0,10 \mathrm{~g}, 0,2 \mathrm{~g}, 0,4 \mathrm{~g}$, dan $0,8 \mathrm{~g}$ dengan timbangan analitik, kemudian masingmasing dilarutkan dengan pelarut DMSO (Dimetil Sulfoksida) 10\% sebanyak $1 \mathrm{ml}$ (Alfiah 2015).

\section{Uji Aktivitas Antijamur}

Inokulum jamur $C$. albicans dimasukkan ke dalam 6 cawan petri steril, kemudian dituang media Potato Dextrose Agar (PDA) sebanyak 10 ml. Cawan petri kemudian digoyang di atas permukaan meja (Laminar Air Flow Cabinet) agar media dan suspensi jamur tercampur lalu dibiarkan selama beberapa menit sampai memadat. Dilakukan pengujian aktivitas antijamur dengan metode difusi agar (Kirby
Bauer) menggunakan pencadang kertas. Pencadang kertas yang telah direndam selama 30 menit dengan larutan uji ekstrak etanol daun pirdot konsentrasi 10\%, 20\%, 40\%, dan $80 \%$, kontrol positif (tablet ketokonazole), dan kontrol negatif (Dimethyl Sulfoxide) diletakkan di atas permukaan media agar padat yang telah diinokulasi jamur dan dibiarkan 15 menit, kemudian diinkubasi dalam inkubator pada suhu $37^{\circ} \mathrm{C}$ selama 24 jam. Setelah itu, diukur diameter daerah hambat di sekitar pencadang kertas dengan menggunakan jangka sorong dilakukan sebanyak tiga kali (Ditjen POM 1995).

\section{HASIL DAN PEMBAHASAN}

Penentuan golongan senyawa kimia simplisia dan EDP dilakukan untuk mendapatkan informasi golongan senyawa metabolit sekunder yang terdapat di dalamnya. Adapun pemeriksaan yang dilakukan terhadap simplisia dan ekstrak adalah pemeriksaan golongan senyawa alkaloid, flavonoid, tanin, saponin, glikosida dan steroid/triterpenoid. Hasil skrining fitokimia serbuk simplisia dan EDP dapat dilihat pada Tabel 1. Pada Tabel 1 menunjukkan bahwa simplisia dan EDP memiliki kandungan senyawa kimia yang sama yaitu alkaloid, flavonoid, tanin, saponin, glikosida (Ningsih 2017, Harborne 1998).

Tabel 1. Hasil skrining fitokimia serbuk simplisia dan ekstrak etanol daun pirdot

\begin{tabular}{|c|l|c|c|}
\hline No & \multicolumn{1}{|c|}{ Skrining } & Simplisia & Ekstrak \\
\hline 1 & Alkaloida & + & + \\
\hline 2 & Flavonoid & + & + \\
\hline 3 & Tanin & + & + \\
\hline 4 & Saponin & + & + \\
\hline 5 & Glikosida & + & + \\
\hline 6 & Steroid/triterpenoid & - & - \\
\hline
\end{tabular}

Semakin besar konsentrasi ekstrak yang diberikan maka semakin besar pula daya hambat yang terbentuk, karena semakin banyak konsentrasi komponen bioaktif yang terkandung di dalam ekstrak. Efektivitas suatu zat antifungal dipengaruhi oleh konsentrasi zat yang diberikan. Meningkatnya konsentrasi ekstrak mengakibatkan tingginya kandungan bahan aktif yang berfungsi sebagai antifungal sehingga kemampuan untuk membunuh pertumbuhan jamur juga semakin besar (De orney et al. 2017). Dalam penelitian ini digunakan ketokonazole sebagai kontrol positif dan DMSO sebagai kontrol negatif (Mulangsri 2014). Kontrol positif berfungsi untuk membandingkan daya hambat dari ekstrak daun pirdot dengan obat kimia yang terbukti dan sering digunakan sebagai antijamur, sedangkan kontrol negatif digunakan untuk mengetahui apakah pelarut yang digunakan dapat mempengaruhi hasil uji antijamur atau tidak (Dewi 2009). Uji kemampuan daya hambat dari ekstrak daun pirdot terhadap pertumbuhan jamur $C$. albicans dilakukan menggunakan 4 konsentrasi, yakni mulai dari konsentrasi $10 \%$, $20 \%$, 40\%, dan $80 \%$ dan menggunakan perbandingan kontrol positif ketokonazole dan kontrol negatif dengan pelarut DMSO steril. Hasil dari uji daya hambat ekstrak daun pirdot terhadap pertumbuhan $C$. albicans dapat dilihat pada Tabel 2. 
Tabel 2. Hasil pengukuran zona hambat ekstrak etanol daun pirdot terhadap jamur Candida albicans

\begin{tabular}{|c|l|c|}
\hline No & Konsentrasi ekstrak & $\begin{array}{c}\text { Rata rata (mm) daya hambat ekstrak } \\
\text { terhadap pertumbuhan jamur }\end{array}$ \\
\hline 1 & EDP 10\% & 8,96 \\
\hline 2 & EDP 20\% & 11,23 \\
\hline 3 & EDP 40\% & 13,50 \\
\hline 4 & EDP $80 \%$ & 18,33 \\
\hline 5 & Kontrol Positif & 21,2 \\
\hline 6 & Kontrol Negatif & 0 \\
\hline
\end{tabular}

Keterangan: EDP $=$ Ekstrak daun pirdot
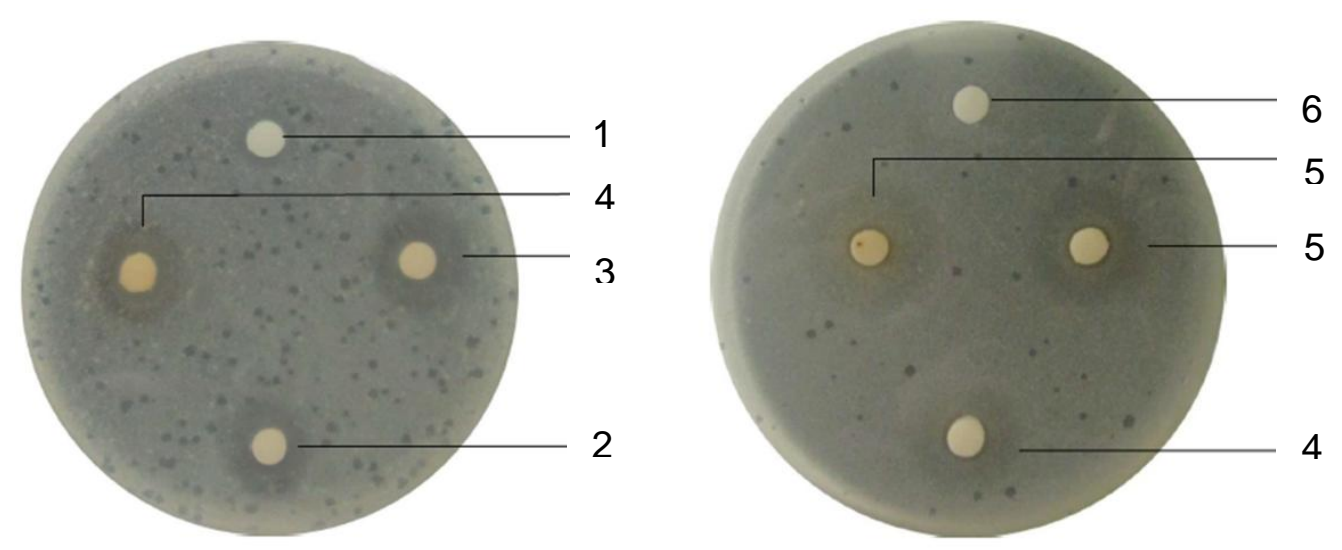

Gambar 1. Hasil pengukuran zona hambat ekstrak etanol daun pirdot terhadap jamur Candida albicans pada beberapa konsentrasi.

Keterangan:

1. EDP $10 \%$

2. EDP $20 \%$

3. $\operatorname{EDP} 40 \%$

4. EDP $80 \%$

5. Kontrol Positif

6. Kontrol Negatif

Pengamatan aktivitas antijamur ekstrak daun pirdot terhadap jamur $C$. albicans dilakukan selama 24 jam. Parameter yang diukur adalah diameter zona hambat yang terbentuk pada tepi daerah kertas cakram. Pengukuran zona hambat yang terbentuk dilakukan dengan mengukur diameter zona bening yang terbentuk dengan menggunakan jangka sorong. Setelah itu zona hambat yang terbentuk dibandingkan dengan diameter zona hambat kontrol positif ketokonazol.

Hasil pengukuran daerah hambat pada Tabel 2 dan Gambar 1 terlihat bahwa semakin besar konsentrasi ekstrak yang diberikan akan menghasilkan daerah hambat yang semakin besar, hal ini disebabkan semakin banyak zat aktif yang terkandung dalam ekstrak. Konsentrasi hambat minimum (KHM) ekstrak daun pirdot adalah pada konsentrasi $10 \%$ yaitu $8,96 \mathrm{~mm}$ dan diameter daerah hambat terbesar

pada konsentrasi $80 \%$ yaitu $18,33 \mathrm{~mm}$. EDP $10 \%, 20 \%, 40 \%, 80 \%$ menunjukkan aktivitas antijamur yang tidak berbeda secara signifikan dengan kontrol positif $(p>0,05)$. Hal ini menunjukkan peningkatan konsentrasi ekstrak herba binara mempengaruhi diameter zona hambat yang terbentuk, diameter zona hambat yang berbeda beda menunjukkan kemampuan ekstrak yang berbeda dalam menghambat pertumbuhan jamur uji (Masloman 2016, Quintin et al. 2012). Aktivitas antijamur dari ekstrak etanol dan fraksi kulit buah sawo manila disebabkan oleh adanya golongan senyawa kimia berupa flavonoid, glikosida, tanin dan steroid/triterpenoid. Senyawa flavonoid memiliki aktivitas antijamur karena flavonoid merupakan golongan senyawa fenol (Febriani 2014, Bhaskara 2012). Tanin termasuk dalam golongan senyawa polifenol sehingga tanin memiliki aktivitas antijamur. Senyawa fenol dan 
turunannya seperti flavonoid dan tanin merupakan salah satu antijamur yang bekerja dengan mengganggu fungsi membran sitoplasma (Octora et al. 2019).

Perbedaan diameter zona hambat ini dapat disebabkan adanya perbedaan kandungan metabolit sekunder yang terkandung pada ekstrak. Hal ini sesuai dengan pendapat Prescott yang menyatakan bahwa ukuran dari zona hambat dipengaruhi oleh perbedaan besar kecilnya konsentrasi ekstrak. Faktor lain yang mempengaruhi perbedaan zona hambat yaitu temperatur inkubasi, waktu pemasangan cakram dan jarak cakram antimikroba (Sudbery 2011, Prescott 2008).

\section{KESIMPULAN}

Hasil uji skrining fitokimia ekstrak daun pirdot (Sauraia vulcani Korth.) terdapat kandungan alkaloid, flavonoid, tanin, saponin, dan glikosida. Flavonoid, tanin, dan saponin terbukti sebagai senyawa yang mempunyai khasiat sebagai antifungal. Ekstrak daun pirdot menunjukkan adanya aktivitas terhadap pertumbuhan jamur $C$. albicans. Hasil pengolahan data konsentrasi hambat minimum ekstrak daun pirdot terhadap pertumbuhan $C$. albicans ini menunjukkan pada konsentrasi terendah yaitu konsentarasi $10 \%$ sudah terlihat dapat mengambat aktivitas pertumbuhan $C$. albicans

\section{UCAPAN TERIMA KASIH}

Terimakasih kepada Kementerian Riset dan Teknologi/ Badan Riset dan Inovasi Nasional yang telah mendanai penelitian ini melalui Hibah Dosen Pemula Tahun 2020 dengan nomor kontrak B/87/E3/RA.00/2020. Terima kasih kepada Institut Kesehatan Meditra Lubuk Pakam atas pemberian penggunaan sarana dan peluang untuk mengikuti kesempatan ini.

\section{DAFTAR PUSTAKA}

Alfiah RR, Khotimah S, Turnip M (2015) Efektivitas ekstrak metanol daun sembung rambat (Mikania micrantha kunth) terhadap pertumbuhan jamur Candida albicans. Protobiont. Vol 4(1), pp 52-7.

https://jurnal.untan.ac.id/index.php/jprb/artic le/view/8735/8710

Al-Kobaisi MF. Jawetz, Melnick \& Adelberg's (2007) Medical Microbiology 24th Edition. Sultan Qaboos University Medical Journal [SQUMJ]. Vol 7(3), pp 273-5.
Arif T, Bhosale JD, Kumar N, Mandal TK, Bendre RS, Lavekar GS, et al (2009) Natural Products-Antifungal Agents Derived From Plants. Journal of Asian Natural Products Researc. Vol 11(7), pp 621-38.

https://doi.org/10.1080/10286020902942350

Bhaskara GY (2012) Uji daya antifungi ekstrak etanol daun salam (Syzygium polianthum) terhadap Candida albicans secara in vitro [skripsi]. Surakarta, Fakultas Kedokteran Universitas Muhammadiyah Surakarta.

Dalimartha S (2006) Atlas Tumbuhan Obat Indonesia Jilid 4, Jakarta, Puspa Swara.

De Ornay AK, Prehananto H, Dewi ASS (2017) Daya Hambat Pertumbuhan Candida albicans dan Daya Bunuh Candida albicans Ekstrak Daun Kemangi (Ocimum sanctum L.), Jurnal Wiyata. Vol 4(1), pp 78-83.

Dewi RC (2009) Uji aktivitas antijamur ekstrak buah pare belut (Trichosanthes anguina L.). Skripsi. Surakarta, Fakultas Matematika Dan Ilmu Pengetahuan Alam Universitas Sebelas Maret.

Ditjen POM (1995) Farmakope Indonesia edisi IV. Jakarta, Depkes RI.

Fagbohun ED, Lawal OU, Ore Me (2012) The Antifungal Activities of the Methanolic Crude Extract of the Leaves of Ocimum gratissimum L., Melanthera scandens A. and Leea guineensis L. on some Phytapogenic Fungi. International Jounal of Biology, vol 1, pp 12-21.

Febriani TH (2014) Uji Daya Antifungi Jus Buah Pare (Momordica charantia L) Terhadap Daya Hambat Pertumbuhan Candida Albicans Secara in vitro. Skripsi. Surakarta, Fakultas Kedokteran Gigi Universitas Muhammadiyah Surakarta.

Gyles CL, Prescott JF, Songer JG, Thoen CO (Eds.) (2008) Pathogenesis of bacterial infections in animals. John Wiley \& Sons.

Harborne JB (1998) Metode Fitokimia: Penuntun Cara Modern Menganalisis Tumbuhan. Bandung: Institut Teknologi Bandung.

Katzung BG, Masters SB, Trevor AJ (2014) Farmakologi Dasar \& Klinik. Vol.2, Edisi 12, Editor Bahasa Indonesia Ricky Soeharsono et al. Jakarta, Kedokteran EGC.

Kurniawan, JA (2009) Uji Aktivitas Antijamur Ekstrak Rimpang Binahong (Anredera cordifolia (Tenore) Steen) Terhadap Jamur Candida albicans serta Skrining 
Fitokimianya [skripsi]. Surakarta: Fakultas Farmasi Universitas Muhammadiyah.

Lippold LE, Draeger T, Teichert A, Wessjohann L, Westermann B, Rosahl S, et al (2009) Actinoomycete Activity Of GammaOxocrotonate Fatty Acids Against Phytophthora infestans. Journal Agricultural and Food Chemical. Vol 57(20), pp 960712. https://doi.org/10.1021/jf902067k

Marbun R, Siregar S, Hasibuan A, Sinurat J, Syarifuddin A, Octora D, Rizky V, Gurusinga R (2019) The Immunomodulatory Activity of Pirdot Leaf Extract (Sauraia Vulcani korth.) on the Immune System of Male Rats. In Proceedings of the International Conference on Health Informatics and Medical Application Technology - Volume 1: ICHIMAT, ISBN.

Masloman AP (2016) Uji Daya Hambat Ekstrak Daun Sirsak (Annona murcata L.) Terhadap Pertumbuhan Jamur Candida albicans. Pharmacon. Vol 5(4). https://doi.org/10.35799/pha.5.2016.13975

Mukherjee PK, Chandra J, Kuhn DM, Ghannoum MA (2003) Mechanism of fluconazole resistance in Candida albicans biofilms: phase-specific role of efflux pumps and membrane sterols. Infection and immunity. Vol 71(8): pp 433340.https://dx.doi.org/10.1128\%2FIAI.71.8.4 3334340.2003

Mulangsri DA, Nurani LH (2014) Aktivitas Antifungi Fraksi Etil Asetat Ekstrak Daun Pacar Kuku Terhadap Candida albicans Resisten Flukonazol. Media Farmasi. Vol 12(1): pp 45-56. http://dx.doi.org/10.12928/mf.v12i1.3017

Nyirjesy P (2001) Chronic vulvovaginal candidiasis. Am Fam Physician. Vol 63(4): pp 697-702.

Muhlisah F (2005) Tanaman Obat Keluarga. Jakarta, Penebar Swadaya.

Ningsih DR (2017) Ekstrak daun mangga (Mangifera indica L.) sebagai antijamur terhadap jamur Candida albicans dan identifikasi golongan senyawanya. Jurnal Kimia Riset. Vol 2(1), pp 61-8. http://dx.doi.org/10.20473/jkr.v2i1.3690

Octora D, Marbun RT dan Koto R (2019) Uji Aktivitas Antibakteri Ekstrak Etanol Daun Pirdot (Saurauia Vulcani korth.) Terhadap bakteri Salmonella thypi. Jurnal farmasimed (JFM), 2(1), 40-44. https://doi.org/10.35451/jfm.v2i1.286

Quintin J, Saeed S, Martens JH, GiamarellosBourboulis EJ, Ifrim DC, Logie C, et al (2012) Candida albicans infection affords protection against reinfection via functional reprogramming of monocytes. Cell host microbe. Vol 12(2): pp 22332.https://doi.org/10.1016/j.chom.2012.06.0 $\underline{06}$

Roking (2007) Identifikasi Golongan Senyawa Dan Aktivitas Antioksidan Ekstrak Metanol, Serta Fraksi Aktif Daun Pirdot (Saurauia vulcani Korth.),[skripsi]. Depok: Fakultas Matematika dan Ilmu Pengetahuan Alam Universitas Indonesia.

Sati SC, Joshi S (2011) Aspects of Antifungal Potentialof Ethnobotanically Known Medicinal Plants. Research Journal of Medicinal Plant. Vol 5(4), pp 377-91. http://dx.doi.org/10.3923/rjmp.2011.377.391

Sherrard J, Donders G, White D, Jensen JS (2011) European (IUSTI/WHO) guideline on the management of vaginal discharge. International journal of STD \& AIDS. 22(8), pp 421-9.

https://doi.org/10.1258/ijsa.2011.011012

Sitorus P (2015) Characterization Simplisia and Ethanolic Extract of Pirdot (Saurauia vulcani, Korth) Leaves and Study of Antidiabetic Effect in Alloxan Induced Diabetic Mice. International Journal of ChemTech Research. Vol8 (6):789-94.

Situmorang RO, Harianja AH, Silalahi J (2015) Karo's Local Wisdom: the Use of Woody Plants for Traditional Diabetic Medicines. Indonesian Journal of Forestry Research. Vol 2(2). pp 121-130.

https://dx.doi.org/10.20886/ijfr.2015.2.2.121 $-130$

Sobel JD (2007) Vulvovaginal candidosis. The Lancet. Vol 369 (9577): pp 1961-71. https://doi.org/10.1016/s01406736(07)60917-9

Sudbery PE (2011) Growth of Candida albicans hyphae. Nature Reviews Microbiology. Vol 9 (10): pp 737-48.

Turnip CD (2014) Uji Daya Hambat Ekstrak Umbi Pakupohon (Cyathea contaminans (Hook.) Copel) Terhadap Jamur Microsporum gypseum Secara In Vitro [skripsi]. Medan, Fakultas Pertanian Universitas Sumatera Utara. 